\title{
Contextual Learning Strategy in the Digital Era at Aisyiyah Fullday Elementary School, Klaten
}

\author{
*Badroh Rif'ati \\ Sekolah Tinggi Agama Islam Muhammadiyah Klaten, Central Java, Indonesia \\ *rifatibadroh@gmail.com
}

\begin{abstract}
The purpose of this study is to identify contextual learning problems in schools and their application in the digital era, where children today tend to return to a perspective that children will learn better if the environment in which they study is a natural environment. This paper is the result of research that uses a logical phenomenon approach, the suggestions and recommendations of this study are expected to increase learning knowledge for both parents, teachers and students to succeed in improving learning outcomes. The method used is qualitative in the form of qualitative descriptive analysis, with semi-structured interviews, focus groups, and participant observation. The findings in this study are that contextual learning at Aisyiyah Fullday Pandes Wedi Elementary School, Klaten, Central Java is accompanied by textual understanding so that there is a student activation process (acquiring knowledge), so students will understand the material optimally.
\end{abstract}

Tujuan penelitian ini adalah mengidentifikasi permasalahan pembelajaran kontekstual di sekolah dan pengaplikasiannya pada era digital, di mana anak-anak dewasa ini cenderung kembali pada sebuah perspektif bahwa anak akan belajar lebih baik jika lingkungan tempat menuntut ilmu adalah lingkungan yang alami. Tulisan ini merupakan hasil penelitian yang menggunakan pendekatan fenomena logis, saran dan rekomendasi dari penelitian ini diharapkan dapat meningkatkan pengetahuan pembelajaran baik orang tua, guru maupun murid agar berhasil dalam meningkatkan hasil belajar. Adapun metode yang digunakan adalah metode kualitatif dalam bentuk analisis diskriptif kualitatif, dengan wawancara semi terstruktur, kelompok fokus, dan observasi partisipan. Temuan pada penelitian ini bahwa pembelajaran kontekstual di Sekolah Dasar Aisyiyah Pandes dibarengi dengan adanya tekstual yang dipelajari, sehingga ada proses pengaktifan siswa (acturing knowledge), maka siswa akan memahami materi secara maksimal.

Keywords: Learning Strategy, Digital Era, Aisyiyah, Fullday School.

Received: July 10, 2020; Revised: Aug 15, 2020; Accepted: Oct 01, 2020 


\section{INTRODUCTION}

One of the prominent characteristics of the digital era is the increasingly interconnected worlds of science and technology so that the synergy between the two becomes even faster. Related to the use of information and communication technology (ICT) in the world of education, it has resulted in more and more learning being offered even though this learning has not been able to bring about the success of students' mastery of science and technology in schools (Shanmugam, 2019).

Therefore, improvement efforts are always carried out by building students, creative, independent and critical without leaving the insight of the responsibility to defend others to be invited to advance to enjoy the opportunities of this era. In this connection, we are challenged to create an educational system that can contribute to the generation of thinkers who can participate in building a knowledge-conscious social and economic order like students today. They must practice using the power of argument and thinking ability, instead of conventional physical strength (Ikhwan, 2018). Of course, in looking ahead and planning our steps, we must not wholly turn away from the reality that binds us to the fact of life.

Various efforts in the context of improving the quality of education are always carried out, including curriculum redesign, learning approaches, structuring content/content, and determining competencies, always adjusted to developments in situations and conditions, as well as the era that occurs. Efforts to improve the quality of education require hard work from all of us, a high willingness and commitment to the task, given the efforts to improve the quality of education, many innovations must be created, creativity must be cultivated, with all the consequences and benefits (Muhayat, 2019).

In the context of education in this digital era, some parties take it as an opportunity. Still, some see it as a challenge or obstacle, or other ways of responding to it, depending on their abilities and perspectives. This simple paper tries to discuss a little about contextual learning in the digital era because there is a tendency today to return to the thought that students will learn better if the environment is created naturally. Learning will be more meaningful if children experience what they learn, not know it. Learning that is oriented towards mastery of the material has proven to be successful in short-term recall competitions but fails to equip children to solve long-term liver problems. Contextual Teaching Learning Approach is to practice learning concepts that link the material being studied with students' real-world situations. Students collectively form a system that allows them to see the meaning in it (Junaidi, 2016).

Contextual Teaching Learning (CTL) assumes that the mind naturally seeks the meaning of the context according to the real situation of one's environment through the search for excellent and useful relationships (Dewi, 2014). Through the material guide studied with students' daily experiences will produce the basics of in-depth knowledge. Students will be able to use their knowledge to solve new problems that they have never faced with increased experience and expertise. Students are expected to be able to build their understanding that will be applied in everyday life by combining the subject matter they have received at school (Cobern, 2012).

However, the question now is: "Are students in the digital age contextual learning capable of critical, literal, systemic thinking, especially in the context of problemsolving because it is based on the Century Learning Framework?" (1) critically and problem-solving (Critical Thinking and Problem-Solving Skills) able to think critically, laterally, and systemically, especially in the context of problem-solving. (2) 
Ability to communicate and collaborate (Communication and Collaboration Skills) able to communicate and collaborate effectively with various parties. (3) Critical thinking and problem-solving skills (Critical Thinking and Problem Solving Skills) able to think critically, laterally and systemically, especially in the context of problemsolving. (4) Ability to communicate and collaborate (Communication and Collaboration Skills) able to communicate and collaborate effectively with various parties. (5) The ability to create and renew (Creativity and Innovation Skills) can develop their creativity to produce multiple innovative breakthroughs. (6) Information and Communications Technology Literacy can utilize information and communication technology to improve performance and daily activities. (7) Contextual Learning Skills can undergo contextual independent learning activities as part of personal development. (8) Information and media literacy skills can understand and use various communication media to convey multiple ideas and carry out collaborative activities and interactions with various parties (Dakabesi, 2019).

To realize the above, the teacher as the spearhead of learning must be able to plan and implement quality PBM, as Aisyiyah Fullday, Pandes Wedi Klaten Elementary School implements a contextual teaching and learning process which is essentially a form of interaction between teachers and students who takes place in teaching situations and to achieve teaching goals. Therefore, researchers are interested in how the learning process carried out by Aisyiyah Fullday Elementary School, Pandes Wedi, Klaten in implementing contextual learning. In this interaction, there will be a process of reciprocal communication between the parties concerned, namely between the teacher and as a teacher and students as students.

Learning behaviour that occurs in students arises as a result of teaching behaviour related to teachers through a form of communication. The type of communication that occurs in the teaching and learning process is referred to as instructional communication, which is related to two-way communication between teachers and students. Therefore, this type of communication is referred to as dialogical communication. With this type of communication, teaching and learning behaviours occur that are interrelated with one another to achieve instructional goals (Mansur \& Yusof, 2018).

\section{Contextual Learning}

Contextual Learning is practising the concept of learning that links the material being studied with students' real-world situations. Students collectively form a system that allows them to see the meaning in it.

In Contextual Learning, eight components must be taken, namely: (1) Making meaningful linkages, (2) doing meaningful work, (3) doing self-regulated learning, (4) working together, (5) thinking critical and creative, (6) helping individuals to grow and develop, (7) achieving high standards, and (8) using authentic assessment.

Contextual Learning is a learning strategy that emphasizes the process of full student engagement to be able to find the material being studied and relate it to real-life situations to encourage students to apply it in their lives (M.P., 2017).

From this concept, there are three things that we must understand. First, Contextual learning emphasizes the process of student involvement in finding material. That is, the learning process is oriented towards the natural experience process. The learning process in the context of Contextual Learning does not expect students only to receive 
lessons, but what is prioritized is the process of finding and finding subject matter by themselves.

Second, contextual learning encourages students to find a relationship between the material being studied and real-life situations. This means that students are required to be able to capture the relationship between learning experiences at school and real life. This is very important because by being able to correlate the material found with real life, the material being studied will be functionally meaningful and embedded in students' memory so that it will not be easily forgotten.

Third, Contextual learning encourages students to be able to apply their knowledge in life. That is, Contextual Learning does not only expect students to be able to understand the material they are learning but how the material can colour their behaviour in everyday life. Subject matter in the context of Contextual Learning is not to be accumulated in the brain and then forgotten but has provisions for them in real life (Mariati \& Rosnita, 2013).

Contextual learning is a learning concept that helps teachers relate the material they teach to situations in the real world of students, and encourages students to make connections between their knowledge and its application in their daily lives. According to Johnson, the contextual learning method is an educational process that aims to help students see the meaning of the academic material they are learning by connecting academic subjects with the context in their daily lives, namely the context of their personal, social and cultural circumstances (Ikhwan, 2017). Students 'knowledge and skills are obtained from students' efforts to construct their new knowledge and skills when they learn.

Contextual learning aims to increase interest and learning achievement and equip students with flexible knowledge, so that it can be applied from one problem to another, and from one context to another. The contextual learning model is a conceptual framework that describes systematic procedures for organizing learning activities to achieve specific goals and serves as a guide for learning designers and teachers in planning and carrying out learning activities. This contextual approach also emphasizes high thinking power, transfer, collect, analyze data, solve specific problems either individually or in groups (Susanto, 2019).

\section{Era Digital}

Currently, the development of technology has arrived at a time when almost all fields are facilitated by technology, especially the internet. People used to call it the digital era; even the government has declared its desire to revolutionize all industries to a higher stage, namely Industry 4.0.

The digital era is a time or period where almost all areas in the order of life have been assisted by digital technology. This term can also be interpreted as the emergence of digital technology that replaces previously used technologies (analogue mechanics and electronics) by humans. The digital era is an era that uses technology (Verano, Husnawati, \& Ermatita, 2020).

One of the closest examples and for sure everyone knows how the internet has changed things. Not only how do we communicate and interact, but also succeed in influencing the business landscape in Indonesia, even in the world. 
The transition of mechanical and electro analogue technology to digital has been very well welcomed by the public, and the rapid development of technology has made us feel a variety of conveniences, even without any restrictions (Bakti, 2014). What used to be local, like this has shifted to a broader scope, even global.

We can very easily communicate, buy, and know the news from places that are geographically very far from where we live. And many other conveniences.

\section{METHOD}

This research method focuses on learning to describe through descriptive, with more emphasis on the type of field research (qualitative). This study used semi-structured interviews, focus groups, and participant observation. The location of this research is an educational institution that uses a contextual learning curriculum. Data were obtained from interviews with school principals, teachers and randomly selected participants. In some cases, contextual learning strategies in the Digital Age are influenced by a lot of unclear news, in this case, educational news or information. The results of the interviews were also analyzed manually; Authors' direct personal investigations should collect information personally from relevant field sources data analysis by Miles and Huberman's model of data presentation and verification and conclusion.

\section{RESULT AND DISCUSSION}

In this digital era, teachers must have good process skills in learning. Process skills can be defined as the skills of teachers in presenting knowledge that can provide meaningful and enjoyable learning experiences for students. Learning centred on students (Student centre) and stimulates students to solve problems (Suarjani, 2019). The teacher's role in PBM is not only as a source of knowledge but also as a facilitator.

Aisyiyah Fullday Elementary School, Pandes Wedi, Klaten, Central Java is an educational institution that uses contextual learning strategies (Cotextual Teaching), which is a learning concept that helps teachers link the material they teach to students' real-world situations and encourages students to make connections between their knowledge and application in everyday life.

In the contextual learning of Aisyiyah Fullday Elementary School, Pandes Wedi Klaten, teachers are required to be able to transfer knowledge to students who already have previous experiences because contextual learning is not an entirely new approach but has been developed previously which is the basis for essential contextual understanding. Has been developed by John Dewey since 1916. This approach was then explored, developed again, and popularized by The Washington State Consortium for Contextual Teaching and Learning ith involving 11 colleges, 20 schools and institutions engaged in education in the United States.

\section{Contextual Learning Strategies}

The practical steps used in the contextual learning strategy at SD Aisyiyah Fullday, Pandes Wedi, Klaten are as follows as the results of interviews conducted by researchers with PAI teachers.; 
First, here every teacher must be able to link learning material with people or figures in the learning material; second, the teacher can tell the character to motivate students' enthusiasm for learning; third, what benefits can be gained from learning a lesson; fourth, as much as possible the teacher can make the material taught in his daily life; then the fifth, giving students freedom of thought; sixth, the talents and interests of these students must be explored and developed by the teacher; and finally all of the above activities must be guided by the teacher (Nurwirastuti, 2020).

From the results of the above interviews it can be concluded;

1) The teacher associates each subject with a character who is successful in applying the issue.

2) The teacher tells or describes in advance the life history of the character or finds the successful ways nature has taken in applying the knowledge he has.

3) The teacher shows clear and specific benefits to students about the knowledge (subjects) being taught to students.

4) The teacher strives for the knowledge learned in school to motivate students to repeat and relate it to their daily lives.

5) The teacher gives freedom to students to construct the knowledge they receive subjectively so that students can find for themselves a natural learning method that suits themselves.

6) The teacher explores the richness of emotions that exist in each student and let them express them freely.

7) The teacher guides students to use emotions in every lesson so that students are meaningful (not in vain in learning at school).

Based on the explanation above, it means that the contextual approach aims to equip students with knowledge that can be flexibly applied (transferred) from one problem to another and from one context to another. By transfer it is expected that: (a) students learn from their own experiences, not from 'giving from others'; (b) skills and knowledge are expanded from a limited context (narrow) little by little; (c) it is important for the student to know "for what" he is studying, and "how" he uses that knowledge and skills.

Various contextual learning strategies carried out by SD Aisyiyah Fullday, Pandes Wedi Klaten as suggested by one of the Mathematics teaching teachers said;

There are at least six strategies that we apply, the first is by presenting problems to students, the second is a free learning environment, the third is control and supervision for students, the fourth encourages interaction with many people, the fifth is group learning, and the last is authentic assessment (Purwanti, 2020).

Based on the explanation above, it means that the contextual approach at Aisyiyah Fullday Elementary School, Pandes, Wedi Klaten can be described as follows;

1) Problem-solving, presenting real problems to students, aims to make students think critically to seek and find solutions through various learning sources.

2) Learning needs occur in various contexts, for example, home, community and workplace. How and where students acquire and generate knowledge becomes very 
meaningful, and this learning experience will be enriched if they learn a variety of skills in a variety of other contexts (home, family, community, workplace and so on)

3) Controlling and directing student learning, so that they become self-regulated learners and subsequently become lifelong learners (long-life education) who can seek, analyze and use various kinds of information.

4) The condition of students is very heterogeneous in terms of values, customs, social and perspectives. This difference is used as a driving force in learning as well as adding to the complexity of contextual learning. Therefore students can appreciate differences and broaden their perspectives and build interpersonal skills (thinking through communicating with others).

5) Encourage students to learn from each other and together with interdependent learning groups. The fact that everyone always lives in togetherness that influences and contributes to the knowledge and beliefs of others.

6) Using authentic assessment means that the review is in line with the learning process that learning has occurred in an integrated manner and provides opportunities and directions for students to progress and as a control tool to see student progress and feedback for education.

\section{Application of Contextual Learning in Schools in the Digital Era}

Learning is said to use a contextual approach if the learning material is not only textual but is related to its application in the daily lives of students in the family, community, natural surroundings, and the world of work, by involving the seven main components so that learning becomes meaningful for students. Any learning model, as long as it meets these requirements, can be said to use a contextual approach. Contextual understanding can be applied in large or small classes, but it will be easier to organize if it is applied in small studies (Munir \& Nur, 2018). The application of contextual knowledge in a competency-based curriculum is very suitable.

In its application, contextual learning does not require enormous costs and select media. Contextual understanding utilizes various sources and learning media in the surrounding environment such as welders, workshops, electronic repairers, used goods, newspapers, magazines, household furniture, markets, shops, TV, radio, internet, and so on. . Teachers and books are not central sources and media, nor are teachers seen as all-rounders, so that teachers do not have to worry about facing student questions related to both traditional and modern environments. As stated earlier, in contextual learning tests are only part of various research techniques or instruments such as interviews, observations, inventory, attitude scales, performance appraisals, portfolios, student journals, and so on, all of which are synergized to assess students' abilities real (authentic).

The assessment is not only from the teacher, but also how the students apply it, it can also be asked of their friends, and other parties such as parents, and people in their environment. In contextual learning, the lesson plan (RPP) is more of a personal plan than as a report for the principal or supervisor as is currently being done. So the lesson plan is more likely to function to remind the teacher himself in applying tools/media and controlling the steps (scenarios) of learning so that the form is more straightforward (Kusmiyati, 2020). 
Some learning models are contextual learning applications here, such as direct learning models, cooperative learning, and also problem-based (Kusmiyati, 2020).

\section{1) Direct Learning Model}

The essence of the direct learning model is that the teacher demonstrates specific knowledge or skills, then practices these skills step by step to students.

Aisyiyah Fullday Elementary School, Pandes Wedi Klaten has the main objectives to be achieved through the learning model, namely mastery of procedural knowledge (knowledge of how to do something, for example, measuring the length of the callipers, working on questions related to the law of conservation of energy, and weighing objects with Ohaus balance), and declarative knowledge (knowledge about something such as the names of the callipers, the distribution of the nonius scale on the micrometre screw, and the functions of the Ohaus balance parts), as well as student learning skills (for example underlining keywords, constructing donkey bridges, create a concept map, and make a summary) (Saputra, Tjhin, \& Zufri, 2014).

Table 1

Syntax of Direct Learning Model

\begin{tabular}{|c|c|}
\hline Phase & Teacher's Role \\
\hline $\begin{array}{l}\text { 1. Convey goals \& prepare } \\
\text { students }\end{array}$ & $\begin{array}{l}\text { The teacher explains the goals \& competencies to be } \\
\text { achieved, background information, lessons, } \\
\text { importance of studies, and prepares students to learn. }\end{array}$ \\
\hline $\begin{array}{l}\text { 2. Demonstrating knowledge or } \\
\text { skills }\end{array}$ & $\begin{array}{l}\text { The teacher demonstrates skills correctly or presents } \\
\text { information step by step. }\end{array}$ \\
\hline 3. Guiding training & Teachers plan \& provide initial training guidance. \\
\hline $\begin{array}{l}\text { 4. Check to understand and } \\
\text { provide feedback. }\end{array}$ & $\begin{array}{l}\text { The teacher checks whether the student has done an } \\
\text { excellent job provides feedback. }\end{array}$ \\
\hline 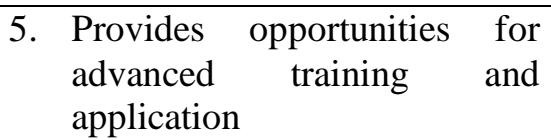 & $\begin{array}{l}\text { Teachers prepare for opportunities for advanced } \\
\text { training, with particular attention to the application to } \\
\text { more complex situations and everyday life. }\end{array}$ \\
\hline
\end{tabular}

The syntax or learning steps include 5 phases, with the teacher's role in each stage can be seen as in table 1 .

This learning model tends to be teacher-centred, so most students tend to be passive, so planning and implementation should be meticulous. The learning management system carried out by the teacher must ensure the involvement of all students, especially in paying attention, listening, and reciting (question and answer). Environmental settings refer to assignments and provide high expectations for students to achieve learning goals.

\section{2) Problem Based Learning Model}

The essence of problem-based learning is that the teacher exposes students to real (authentic) and meaningful problem situations, facilitates students to solve them through inquiry and cooperation, facilitates dialogue from various aspects, stimulates students to produce cracking work and demonstrates results. The theoretical rationale that underlies this model is Piaget and Vygotsky's theory of constructivism, as well as Bruner's theory of discovery learning. According to constructivism theory, knowledge 
cannot be transferred from teacher to student like pouring water in a glass. Still, students construct their knowledge through intra-individual processes of assimilation and accommodation (according to Piaget) and inter-individual or social processes (according to Vigotsky). According to Bruner, real learning occurs through discovery, so that in the learning process, there should be many opportunities for student discovery activities. The objectives that can be developed through this learning model are thinking and problem-solving skills, performance in dealing with real-life situations, forming autonomous and independent learners (Kurahman \& Ali, 2016).

The syntax or learning steps include 5 phases, with the teacher's role in each stage can be seen as in table 2 .

Table 2

Syntax of Problem Based Learning Model

\begin{tabular}{|c|c|}
\hline Phase & The Role of the Teacher \\
\hline $\begin{array}{l}\text { 1. Orient students to the } \\
\text { problem }\end{array}$ & $\begin{array}{l}\text { The teacher explains the } \\
\text { objectives/competencies to be achieved, } \\
\text { explains the logistics required, motivates } \\
\text { students to be involved in the selected problem- } \\
\text { solving activities. }\end{array}$ \\
\hline $\begin{array}{l}\text { 2. Organizing students to } \\
\text { learn }\end{array}$ & $\begin{array}{l}\text { The teacher helps students define and organize } \\
\text { learning tasks related to these problems. }\end{array}$ \\
\hline $\begin{array}{l}\text { 3. Guiding individual and } \\
\text { group inquiry }\end{array}$ & $\begin{array}{l}\text { The teacher encourages students to collect } \\
\text { appropriate information, carry out experiments } \\
\text { to get explanations and problem-solving. }\end{array}$ \\
\hline $\begin{array}{l}\text { 4. Develop and present the } \\
\text { work }\end{array}$ & $\begin{array}{l}\text { The teacher assists students in planning and } \\
\text { preparing appropriate work such as reports, } \\
\text { videos, or models, and helps them to share } \\
\text { assignments with friends. }\end{array}$ \\
\hline $\begin{array}{l}\text { 5. Analyze and evaluate the } \\
\text { problem-solving process }\end{array}$ & $\begin{array}{l}\text { The teacher helps students to reflect or evaluate } \\
\text { their investigations and the processes they use }\end{array}$ \\
\hline
\end{tabular}

The learning environment and management system in this problem-based learning model are characterized by an open nature, a democratic process, and the active role of students. The whole process is oriented towards helping students become independent, autonomous, trusting in their intellectual skills through active involvement in an open inquiry-oriented environment and free to express opinions.

\section{3) Cooperative Learning Model}

The essence of this learning model is that it is expected that elementary school students Aisyiyah Fullday, Pandes Wedi Klaten can learn in small groups, whose members have different levels of ability (heterogeneous), wherein understanding a lesson material and completing group assignments, each member cooperate until all members master the lesson material. In its variations, there are many types of cooperative learning approaches, for example, STAD (Student Teams Achievement Division), Jigsaw, Group Investigation, and Structural Approaches. Still, these are not addressed in this training material (Muslim, 2017).

The theoretical rationale that underlies this model is Vigotsky's constructivism theory which emphasizes the importance of sociocultural in the learning process as 
mentioned earlier, and John Dewey's pedagogical theory which states that the class should be a miniature of society and function as a laboratory for real-life learning (Lenin, 2020). The teacher should create in his learning environment a social system characterized by democracy and a scientific process .

The goal to be achieved through this learning model is the academic learning outcomes of elementary school students Aisyiyah Fullday, Pandes Wedi, Klaten, namely, mastery of difficult concepts, which through cooperative groups are easier to understand because of the presence of peer tutors, who have a different orientation and language. Besides that, the results of learning social skills in the form of collaborative skills (cooperation and collaboration) can also be developed through this learning model (Prayoga, 2017).

The syntax or learning steps include 6 phases, with the teacher's role in each stage can be seen in table 3 .

Table 3

Syntax of Cooperative Learning Model

\begin{tabular}{ll}
\multicolumn{1}{c}{ Phase } & \multicolumn{1}{c}{ Teacher's Role } \\
\hline $\begin{array}{l}\text { 1. Convey goals and } \\
\text { motivate students }\end{array}$ & $\begin{array}{l}\text { Teachers convey the goals/competencies to be } \\
\text { achieved and encourage students to learn }\end{array}$ \\
\hline 2. Presenting information & $\begin{array}{l}\text { The teacher presents information to students by } \\
\text { way of demonstrations or through reading material }\end{array}$ \\
\hline $\begin{array}{l}\text { 3. Organizing students into } \\
\text { study groups }\end{array}$ & $\begin{array}{l}\text { The teacher explains to students how to form study } \\
\text { groups and helps each group to make the transition } \\
\text { efficiently }\end{array}$ \\
\hline $\begin{array}{l}\text { 4. Guide group work and } \\
\text { study }\end{array}$ & $\begin{array}{l}\text { The teacher guides study groups as they work on } \\
\text { their assignments }\end{array}$ \\
\hline 5. Evaluation & $\begin{array}{l}\text { The teacher evaluates the learning outcomes of the } \\
\text { material that has been studied, or each group } \\
\text { presents the results of their work }\end{array}$ \\
\hline 6. Give awards & $\begin{array}{l}\text { Teachers look for ways to reward both individual } \\
\text { and group learning efforts and outcomes }\end{array}$
\end{tabular}

The learning environment and management system in this cooperative learning model is characterized by a democratic process and the active role of students in determining what to learn and how to learn it. In environmental settings, it is endeavoured to make complete learning materials available and accessible to every student, and teachers to stay away from the traditional mistake of strictly managing student behaviour in group work.

\section{CONCLUSION}

Schools in preparing students must address the development of science and information technology. Because in this digital era, it requires mastery of critical thinking, mastering information technology, being able to collaborate and be communicative. The process of achieving these skills is carried out using intellectual and contextual learning, which in the context of the national education system is 
recommended to analyze competency standards and essential competencies of each class, to provide sufficient space in several subjects which can then be used for student contextual learning. Because students naturally have daily experiences and will produce a combination of the basics of in-depth knowledge, students are also expected to be able to build their understanding that will be applied in everyday life by combining the subject matter that has been received in school.

\section{REFERENCES}

[1] Bakti, A. F. (2014). Trendsetter Komunikasi di Era Digital : Tantangan dan Peluang Pendidikan Komunikasi dan Penyiaran Islam. Jurnal Komunikasi Islam, 04(1), 2044.

[2] Cobern, W. W. (2012). Contextual Constructivism: The Impact of Culture on the Learning and Teaching of Science. In K. G. Tobin (Ed.), The Practice of Constructivism in Science Education (1st ed., pp. 67-86). New York: Routledge. https://doi.org/10.4324/9780203053409-9

[3] Dakabesi, D. (2019). The effectiveness of problem-based learning model to increase the students critical thinking skills. Journal of Education and Learning (EduLearn), 13(4), 143-157.

[4] Dewi, N. P. I. R. (2014). Penerapan Model Contextual Teaching and Learning Berbantuan Media Alam untuk Meningkatkan Kemampuan Motorik Halus pada Anak. Jurnal Pendidikan Anak Usia Dini Undiksha, 2(1), 1-10.

[5] Ikhwan, A. (2017). Development Of Quality Management Islamic Education In Islamic Boarding School (Case Study Madrasah Aliyah Ash Sholihin). Al-Hayat: Journal of Islamic Education, 1(1), 117. Retrieved from http://alhayat.or.id/index.php/alhayat/article/view/7

[6] Ikhwan, A. (2018). Management of Learning Assesment Using Curriculum 2013 (Case Study in Islamic Primary School (MI) Muhammadiyah 5 Wonoasri Ponorogo - East Java - Indonesia). MUADDIB: Studi Kependidikan Dan Keislaman, 08(02), 108-123. https://doi.org/10.24269/muaddib.v8i2.1422

[7] Junaidi, K. (2016). Sistem Pendidikan Pondok Pesantren di Indonesia (Suatu Kajian Sistem Kurikulum di Pondok Pesantren Lirboyo). Istawa: Jurnal Pendidikan Islam, 2(1), 95-110. https://doi.org/10.24269/ijpi.v2i1.364

[8] Kurahman, T., \& Ali, M. (2016). Perbedaan Hasil Belajar Fisika Antara Menggunakan Model Problem Based Learning dengan Model Direct Intruction pada Siswa Kelas VII SMP Negeri 14 Palu. JPFT (Jurnal Pendidikan Fisika Tadulako Online), 4(2), 27-30.

[9] Kusmiyati. (2020). Wawancara Langsung: Tenaga Administrasi SD Aisyiyah Fullday, Pandes Wedi, Klaten.

[10] Lenin, K. (2020). Minimization of real power loss by enhanced teaching learning based optimization algorithm. IAES International Journal of Robotics and Automation (IJRA), 9(1), 1-5. https://doi.org/10.11591/ijra.v9i1.pp1-5

[11] M.P., B. (2017). Contextual Teaching and Learning the Effective Strategy for Contextualization of Teaching and Learning (1st ed.). New Delhi: New Century Publications. 
[12] Mansur, A. B. F., \& Yusof, N. (2018). The Latent of Student Learning Analytic with K-mean Clustering for Student Behaviour Classification. Journal of Information Systems Engineering and Business Intelligence, 4(2), 156-161.

[13] Mariati, N., \& Rosnita, R. (2013). Peningkatan Keterampilan Proses Siswa Melalui Pendekatan Contextual Teaching And Learning (Ctl) Pada Pembelajaran Matematika Kelas V Sekolah Dasar Negeri 07 Siantan Kabupaten Pontianak. Jurnal Pendidikan Dan Pembelajaran Khatulistiwa, 12(2), 1-11.

[14] Muhayat, I. (2019). Development of Teacher Position in Islamic Education Institutions: Teachers as Professional Educators. Istawa: Jurnal Pendidikan Islam, 4(1), 1-14. https://doi.org/10.24269/ijpi.v4i1.1640

[15] Munir, \& Nur, R. H. (2018). The Development Of English Learning Model Based On Contextual Teaching And Learning (CTL) In Junior High Schools. International Journal of Language Education, 2(1), 31-39.

[16] Muslim, B. (2017). MENINGKATKAN HASIL BELAJAR PENGAMBILAN KEPUTUSAN BERSAMA MELALUI METODE BERMAIN PERAN DENGAN MODEL PEMBELAJARAN COOPERATIVE LEARNING Buhari Muslim. AtTa'lim : Media Informasi Pendidikan Islam, 16(2), 309-324.

[17] Nurwirastuti, Z. (2020). Wawancara Langsung: Guru Pendidikan Agama Islam SD Aisyiyah Fullday, Pandes Wedi, Klaten.

[18] Prayoga, A. (2017). Peningkatan Kemampuan Penalaran Matematika Enggunakan Model Pembelajaran Problem Based Learningpada Siswa Kelas VIII. EKUIVALEN - Pendidikan Matematika, 31(1), 31-36.

[19] Purwanti, N. (2020). Wawancara Langsung: Guru Matematika SD Aisyiyah Fullday, Pandes Wedi, Klaten.

[20] Saputra, D., Tjhin, S., \& Zufri, T. (2014). SIPEBI: A Model of Cultural Edutainment Web Portal as a Medium for Students Self-Directed-Learning and Alternative Assessment. International Conference on Education and Language, 1(1), 1-14.

[21] Shanmugam, K. (2019). Motivation in Information Communication and Technology Based Science Learning in Tamil Schools. Jurnal Pendidikan IPA Indonesia, 8(1), 1-11.

[22] Suarjani, N. W. (2019). Student Centre Learning ( Scl) Dalam Pembelajaran Di Sekolah Dasar. Adi Widya: Jurnal Pendidikan Dasar, 4(1), 40-46.

[23] Susanto, T. (2019). Banten Children's searning Palace Social Campaign in Development of. Jurnal Komunikasi Pembangunan, 17(2), 205-215.

[24] Verano, D. A., Husnawati, H., \& Ermatita, E. (2020). Implementation of Autoregressive Integrated Moving Average Model to Forecast Raw Material Stock in The Digital Printing Industry. Journal of Information Technology and Computer Science, 5(1), 1-17. 